\title{
Design of an Integrated Land Use and Activity-Based Travel Model System for the Puget Sound Region
}

\author{
Paul Waddell \\ University of Washington \\ Daniel J. Evans School of Public Affairs \\ Box 352055 \\ Seattle, WA 98195 \\ Fax: 206-685-9044 \\ Phone: 206-221-4161 \\ Email: pwaddell@u.washington.edu \\ Maren Outwater \\ Cambridge Systematics, Inc. \\ $3239198^{\text {th }}$ Place, SE \\ Issaquah, WA 98029 \\ Phone: 425-837-1450 \\ Fax: 425-837-1449 \\ Maren_Outwater/oak/camsys@camsys.com \\ Chandra Bhat \\ University of Texas \\ Department of Civil Engineering \\ Ernest Cockrell Jr. Hall, 6.810 \\ The University of Texas at Austin \\ Austin, Texas 78712 \\ Fax: (512) 475-8744 \\ Phone: (512) 471-4535 \\ bhat@mail.utexas.edu \\ Larry Blain \\ Puget Sound Regional Council \\ 1011 Western Avenue, Suite 500 \\ Seattle, Washington 98104-1035 \\ Fax: (206) 587-4825 \\ Phone: (206) 464-7090 \\ lblain@psrc.org
}

word count: 7086 


\begin{abstract}
This paper presents the results of a design process for new integrated land use and transportation models recently completed for the Puget Sound Regional Council (PSRC). The design process began with an analysis of policy requirements and assessment of the current models in use at the PSRC and nationally, and used an iterative and participatory approach to ensure that model requirements were clearly identified and that the proposed model design would address these requirements. The development of the model requirements drew on a broad survey of the literature and of operational models, and the proposed model design offers a unique approach to the development of a new land use and travel model system that corresponds to a behavioral integration of the choice processes across relevant time frames.
\end{abstract}

\title{
INTRODUCTION
}

This paper contains an assessment of requirement for new model development at the Puget Sound Regional Council (PSRC) and a set of recommendations for model design and implementation. A broad review of the literature and of operational models was conducted as part of this project, but is omitted due to space limitations. Based on emerging requirements for the use of land use and transportation models to support a growing range of policy questions relevant to transportation, land use and growth management, the Regional Council initiated in 2000 an effort to design new land use and transportation models as a long-term model improvement effort. The first stage in this effort was the identification of requirements for new model development, which emerged principally from an assessment of the kinds of policies that the Regional Council intends to examine, and the indicators and evaluation measures that need to be generated by the models to support systematic assessment of policy scenarios.

In the next section, we examine the policy context for the use of land use and transportation models at the PSRC. We then turn to an assessment of requirements for new model development, including a survey of staff from the PSRC and constituent local governments, and describe the recommendations for a behaviorally integrated model system to address these requirements, and discuss implementation issues. A brief conclusion identifies the main advantages of the proposed approach.

\section{The Policy Context}

In Washington, as in most of the rest of the United States, growth management is a focal point of policy discussions as municipalities struggle to accommodate demands generated by growing population and growing average resource consumption. The United States Census figures show that the population in the four-county Puget Sound region has reached 3.8 million (U.S. Census, 2000), an increase of $19 \%$ since 1990. One forecast for 2020 puts the population at 4.26 million, with the average household size dropping to 2.34 (PSRC, 1999). Housing prices continue to escalate, the salmon listing imposes new restrictions on development, and congestion continues to worsen. At the same time, tax limitation initiatives limit the ability of government to raise taxes to fund public infrastructure investments. Planners and policymakers strive to find the delicate balance between consumer demand, environmental quality, water resources, and social needs. The Regional Council also weighs these conflicting demands in its role as a Metropolitan Planning Organization (MPO) and a Regional Transportation Planning Organization (RTPO).

The Puget Sound Regional Council is an association of cities, towns, counties, ports, and state agencies in the area encompassing King, Pierce, Snohomish and Kitsap counties, with the charge of coordinating growth management, economic and transportation efforts in the Puget Sound region. While land use decisions are a local matter, the Regional Council oversees the consistency of local decisions with the regional and state planning requirements. The Regional Council's responsibilities fall into six broad categories: transportation, growth management, countywide comprehensive plans, regional data base development, technical assistance, and discussion forum. In order to fulfill its responsibilities, the Regional Council develops policy initiatives that encourage development that is consistent with the region's transportation and land use goals. Current high priority items include:

- Congestion Management System (CMS) - Federal legislation mandates that metropolitan areas of the size of the Puget Sound Region develop a CMS. Initiatives include Commute Trip Reduction programs, Transportation Demand Management (TDM), Transportation Systems Management (TSM) and data gathering. 
- Freight Action Strategy (FAST) - This is a multi-jurisdictional program, with governmental and private business partners working to evaluate and consider freight mobility projects as part of the overall regional transportation strategy.

- Intelligent Transportation Systems (ITS) - ITS is a multi-faceted approach to maximizing the efficiency of the region's transportation system. ITS initiatives include metering highway on-ramps and distribution of traveler information.

- Monitoring Regional Progress - The Regional Council is working on a regional monitoring program that will track the region's progress towards achieving the goals articulated in VISION 2020.

- Pricing - The Regional Council is investigating a politically feasible method of changing the pricing of the Puget Sound Region's transportation system. Issues under consideration by the Transportation Pricing Task Force include a vehicle miles traveled tax, a fuel tax, parking charges and a congestion pricing scheme.

- Regional Planning Functions - The Regional Council, as required by federal legislation such as ISTEA and the Clean Air Act Amendments and state legislation such as the Growth Management Act, prepares a regional growth management, economic and transportation strategy and regional transportation plan. VISION 2020, the Regional Council's comprehensive plan, was updated and adopted by regional cities and counties in 1995.

- Transit Station Communities Project - The Regional Council is working with 1000 Friends of Washington on a two-pronged campaign: 1) increase awareness of station area development opportunities throughout the fourcounty region, and 2) work directly with local governments to provide technical assistance at selected transit station locations.

The Regional Council uses models to help understand how different investments in transportation infrastructure and programming will affect the Puget Sound region. By creating different sets of policy and population assumptions, planners can forecast results of different policy scenarios. The structure of the model and the variables that make up the model will determine which sorts of scenarios the model can test most accurately.

There are a number of methods to compare different policy scenarios based on the outcomes produced by models. In developing plans for the future and assessing alternatives, the Regional Council is required by state law (RCW 47.80.030) to perform Least-Cost Planning (LCP) analysis. LCP places all alternatives on an equal basis for analysis. This form of analysis forces consideration of direct and indirect costs to find the most efficient mix of services. The Regional Council also uses cost-benefit analysis in evaluating alternatives. This process assigns monetary values to the costs of providing the program under evaluation as well as the benefits derived. The process of calculating the values can be controversial, since some items are intangible and therefore hard to value. A third method is to compare forecasted values for agreed upon indicators. In addition to using model projections to analyze options while policies are under consideration, the Regional Council uses data to track performance of adopted policies or strategies. Assessing the performance of various scenarios with the indicators makes informed choices possible. The variables used to construct the model should be also be useful in performance evaluation to make most efficient use of data.

In preparing for the design of new models over an extended period, the Regional Council staff have been interviewed to identify limitations or concerns regarding the current model system, that make it difficult to achieve the kinds of policy analysis outlined above. The model design team also distributed a survey to the Regional Council members and staff to solicit input on the current models and ideas for revisions. In addition, the recent period of comment on the Metropolitan Transportation Plan Draft Environmental Impact Statement provided a range of comments and concerns by member agencies and others, some of which relate to the current model system. These concerns provide valuable information that was taken into consideration in designing new models.

The concerns raised about the state of the practice in land use and transportation planning closely match concerns raised nationally, since the current PSRC models are similar to those used in other metropolitan areas. The PSRC uses the DRAM/EMPAL models developed by Putman to predict land use, and a four-step travel model. The Transportation Model Improvement Project (TMIP) organized a conference on Land Use Modeling in 1995, at which practitioners, consultants, and academics reviewed the state of the practice in land use and transportation modeling and raised suggestions for model improvement. These concerns and recommendations are summarized in Table 1.

[Table 1 here] 


\section{REQUIREMENTS FOR NEW MODEL DEVELOPMENT}

Based on the assessment of the Regional Council policy context, and the state of operational land use and transportation modeling in the U.S., the following draft requirements and recommendations were proposed in January, 2001 to guide the long-term design of new Regional Council land use and transportation models. The requirements were given as fundamental requirements that any proposed model design must meet if it is to be considered acceptable to the Regional Council. Recommendations are features that the model design should attempt to address, but must be weighed against costs and other considerations.

The requirements are divided into categories based on design elements identified for the model review process. These will form the structure for the subsequent working papers that provide a review of the literature and of operational models, and offer recommendations for the design of new land use and transportation models.

\section{Policy Analysis}

Analyze Effects of Transportation Pricing Policies The model system must be sensitive to the effects of transportation pricing policies on both travel behavior and land use.

\section{Analyze Effects of Growth Management Policies}

- As part of the review of local comprehensive plans for consistency with the requirements of the Growth Management Act, the model system must be able to address the impacts of proposed land use and transportation policies on housing affordability.

- The model system must be able to support the role of the Regional Council in monitoring development and compliance with the objectives of VISION 2020 and the Growth Management Act. Use of monitoring information should also be made in ongoing model refinement.

\section{Analyze Effects of Land Use Policies}

- In order to evaluate the potential effects of land policies on achievement of the urban villages strategy outlined in VISION 2020, the model system must be sensitive to policies that are designed to promote densification, infill and redevelopment.

- The model system must be sensitive to the effects of land use policies such as comprehensive land use plans, zoning, and the Urban Growth Boundary on real estate development and the location of households and firms.

Analyze Short and Long-term Policy Effects The model system must be able to assess policy effects over periods ranging from less than 5 years to 30 years.

Support Participatory Policy Process The model system must be designed to support a participatory policy process that includes activities such as VISION 2020, where scenarios are generated and publicly discussed. Public access to the model assumptions, theory, structure, and results is required, and the models must be explainable to a nontechnical audience.

Support Scenario Assessment The model system must support the creation of performance indicators and evaluation measures suitable for use by the Regional Council in evaluating alternative policy scenarios using, at a minimum, Least Cost Planning and Cost Benefit Analysis techniques.

\section{Travel Demand}

Analyze Travel Using Activity-based Framework The new travel models must be based on an activity-based framework in order to adequately represent the complexity and constraints of travel behavior, and influence of land use and transportation policies on travel behavior.

Analyze All Modes of Travel

- The model must allow comparison of different transit modes, for example rail vs. bus.

- The new model system must be capable of adequately representing non-motorized travel behavior.

- The model must allow comparison of different auto modes of travel, for example HOV with 2 or $3+$ person vs. SOV. 
Analyze Effects of Land Use on Transportation To support integrated planning, the model must recognize the impact of land use patterns on demand for transportation.

Analyze Induced Demand The model system must allow analysis of demand induced by transportation system improvements.

Analyze Effects of Environmental Factors The model system must be able to assess the impacts of environmental regulations that affect the development of environmentally sensitive lands, such as Salmon habitat, wetlands, floodplains, seismic areas, steep slopes, and other sensitive lands.

Analyze Effects of Travel Demand Management (TDM) Policies The model system must be able to assess the impacts of commute trip reduction and TDM policies, such as different work arrangements (flexible versus fixed work schedule, telecommuting or not, compressed work week or regular work week).

\section{Land Use and Demographics}

Analyze Effects of Transportation on Land Use To support integrated land use and transportation planning, the model must recognize the effects of multi-modal transportation system and policy changes on real estate development and the location patterns of households and firms.

Analyze Effects of Urban Design The model system must be sensitive to the effects of urban design elements such as mixed land use, density, street pattern, transit service and pedestrian amenities on household and firm location and travel behavior.

\section{Analyze Household Choices}

- The new model system must be able to analyze the residential movement and location choices made by households, and the influence on these choices of relevant housing and location characteristics.

- The new model system must be able to model the choice of household members to participate in the labor market, and to choose a work location.

- The new model system must be able to model the vehicle ownership choices of households.

Analyze Household Choice Interactions The new model system must be able to analyze the interactions between household choices related to residential mobility and location, labor market participation and workplace, vehicle ownership, and daily activity and travel scheduling.

Analyze Demographic Processes The new model system must be able to represent demographic processes such as the change in household size and structure, and the ageing of the population.

\section{Analyze Real Estate Development}

- The new model system must incorporate a component to model the process of real estate development, including infill and redevelopment, and the effects of various policies on this process.

- The new models must distinguish between important types of real estate that are relevant to the goals and objectives of Vision 2020, including adequate representation of different nonresidential, residential, and mixeduse types.

Support Analysis of TOD The new model system must be able to support the analysis of Transit Oriented Development, including real estate development, household and business location, to assist in station area planning.

\section{Analyze Economic Activity}

- The new model system must incorporate a macroeconomic component to model economic growth in the region and its relationship to internal and external economic drivers.

- Analyze the factors and policies influencing the location choices and real estate demands of different firms in different industries. 


\section{Freight}

Analyze Commodity and Freight Transport The new models must address freight and commodity transport within and through the region.

Analyze Modal Diversion of Goods Movement The new models must address modal choices and tradeoffs of moving goods by truck, rail, barge or air.

\section{Assignment and Traffic Operations}

Analyze Multimodal Assignments The model system should be able to produce multi-modal travel assignments for roadway, transit and possibly non-motorized systems.

Analyze Traffic Operations

- The model should contain information pertinent to Commute Management Systems (CMS) policies such as workplace incentives, telecommuting, and a greater breakdown of carpool sizes.

- The model should provide information showing the effects of Transportation System Management (TSM) initiatives.

Analyze Intelligent Traffic Systems (ITS) The model system should provide output relevant to policies instituted as part of ITS such as an incident management system or public information distribution.

\section{Data/Visualization and Evaluation}

Promote Common Use of Data

- The Regional Council should take into account the use of its model input, structure and output by other agencies, member governments and other outside users.

- The model system must be developed in a way that supports open and unrestricted access to the software by Regional Council staff, consultants, and constituents, in order to maintain and modify the models to meet emerging needs over time.

- The model system should support distributed access and use by Regional Council member governments, and should use consistent data for Regional Council and member agency applications.

Manage Data Needs The new model system must be manageable from the perspective of its data requirements. Achieve Reasonable Performance - The model system must have reasonable performance, in terms of computational efficiency, so that an entire run of the full land use and transportation model system can be accomplished within one working day.

\section{Support Visualization Techniques}

- The model system must provide tools to facilitate visualization of model results and comparison of scenarios in ways that are useful to non-technical audiences.

- The model must provide forecasts of system characteristics tracked by state benchmarks, for example, the benchmarks identified by the Blue Ribbon Commission on Transportation.

- The model system must produce output that allows analysis of the best mix of transportation investments.

Allow Multi-Modal Cost-Benefit Analysis This ability would enable model users to make more informed transportation investment decisions.

Perform Uncertainty Analysis The model must address uncertainty in the models and produce ranges of values for outputs rather than specific results to be more accurate.

\section{USER-NEEDS ASSESSMENT}

In order to obtain systematic input on the draft requirements for the model development effort, the Regional Council distributed a survey by email, on paper, and on the web to many public agencies around the Puget Sound Region, in addition to their own staff. Respondents rated 31 potential requirements for the design of new land use and transportation models. Sixty-one individuals responded to the survey over a two-month period. The respondents 
work primarily in transportation-related positions (45 of 61 respondents, or $74 \%$ ), at a mixture of jurisdictional levels, as shown in Table 2.

[Table 2 here]

Respondents rated each of the 31 requirements from "Very Important" to "Opposed to Inclusion". For the purpose of analysis, requirements rated Very Important received 2 points, requirements rated Important received 1 point, requirements rated Not Important received 0 points, and requirements rated Opposed to Inclusion were omitted from the average. Of the 31 requirements, only one, Analyze Effects of Environmental Factors, received four or more ratings of opposed to inclusion. A summary of these survey results is shown in Table 3.

[Table 3 here]

The most important ratings (with the highest average ratings) went to requirements related to travel demand, policy analysis, and data visualization and evaluation. The criteria receiving the highest ratings were "Analyze Effect of Land Use on Transportation" at 1.76, which was the only item receiving only 1 and 2 ratings, and "Analyze Multimodal Assignments", at 1.74. The lowest rating went to "Analyze Intelligent Traffic Systems (ITS)". The average responses for individual requirements in each category vary, but the Policy requirements are generally rated as more important than the Land Use and Demographic requirements. When using the category divisions based on supply and demand, both Demand for Travel and Implementation have two items in the top five requirements, while Measuring Impact and Demand for Travel are represented twice in the bottom five. Demand for Travel, with "Analyze Effect of Land Use on Transportation" at the top of the requirement ratings and "Analyze Intelligent Traffic Systems (ITS)" at the bottom, had the most divergent ratings. Figure 1 shows the number of respondents who rated each requirement 1 or 2 (important) as the dark bar, or 3 or 4 (unimportant or opposed to inclusion) as the striped area at the right. Shorter bars indicate that some respondents skipped the question.

[Figure 1 here]

\section{MODEL DESIGN RECOMMENDATIONS}

The recommendations for developing new land use and travel demand models for use by the PSRC and its member governments draw on the analysis of policy requirements and on a review of the literature and operational models, as well as on the results of the model validation and data assessment tasks of this project.

The key highlights of these recommendations for the model design are:

- Represent real estate, labor and transportation demand and supply market interactions, as shown in Figure 2, within an integrated model system, as shown in Figure 3.

- Represent real estate and labor demand and supply, and their interaction, as dynamic processes using annual time periods, at the parcel level.

- Represent the temporal dimensions of activity and travel demand using as much detail that is practical for implementation. In the mid-term recommendations, we recommend 5 or more discrete time periods per day, and in the long-term recommendations, we recommend considering using 5-10 minute intervals (or continuous time) per day. Represent activity locations at the parcel level.

- Represent behavior according to agent and time frame, rather than in traditional model components that artificially separate land use and transportation:

Household Housing Demand, Labor Supply and Vehicle Demand: Represent household choices of residence, workplace, and vehicle ownership in an integrated model component of long-term household choices, influenced by multi-modal (including non-motorized) accessibility to activities.

Person Vehicle Allocation, Activity Generation and Tour Pattern: Represent intra-household vehicle allocation, activity generation and scheduling, and stop and tour locations and characteristics, within an integrated personal travel demand model component, closely interacting with long-term household choice model.

Business Real Estate and Labor Demand, Commodity Transport Demand: Represent business choices of location, employment level, and commodity transport in closely integrated model components.

Real Estate Supply: Represent developer choices of new construction and redevelopment of housing and nonresidential space in an integrated model component. 
Transportation Supply: Represent multi-modal transportation system supply, including non-motorized modes.

- Real Estate Market Interactions: Represent interactions of real estate demand and supply, and the resulting vacancy and price effects.

- Labor Market Interactions: Represent interactions of labor supply and demand, and the resulting vacancy and wage effects.

- Transportation Market Interactions: Represent interactions of travel demand and supply, and the resulting patterns of congestion delay and travel volume.

These recommendations for the design of the new models are further detailed by model component in Tables 4 through 7, addressing the land use, passenger travel, freight, and assignment components, respectively. Table 8 details the recommendations for representation of agents, objects and behavior for the land use and travel models.

\section{MODEL IMPLEMENTATION RECOMMENDATIONS}

Given the model design recommendations highlighted in the preceding section, the following recommendations address the questions of implementing the proposed model design. Here, we differentiate more clearly between short-range, mid-range and long-range recommendations, and deal with more specific aspects of financial and time constraints, and opportunities for leveraging resources through cooperative development efforts. For brevity, shortterm recommendations closely tied to the existing PSRC models are omitted from this discussion.

\section{Mid-term Implementation}

In the mid-term (through mid-2005):

- Replace the current land use and travel demand forecasting models with an integrated land use and activitybased model:

- Replace DRAM/EMPAL land use models with a new model that reflects the characteristics proposed in Table 4.

- Integrate long-term household choices of residential location, workplace, and vehicle ownership to reflect their interdependence.

- Interact with short-term choices of daily activity and travel through multimodal access measures.

- Replace the trip generation, distribution, mode choice and time of day components of the current travel demand models with an activity-based travel model system with the characteristics proposed in Table 2. This model will be adapted from the Portland and San Francisco activity-based models, using a discrete-time approach with 5 periods per day.

- Add a visitor trip model to the resident travel model component. This will involve conducting a travel survey of visitor behavior.

- Integrate regional economic, land use, activity based travel model components within an integrated software application, with the following extensions:

- Add data integration component that assists in diagnosing data quality and consistency, and in the integration and refinement of data inputs for modeling.

- Add evaluation component that includes flexible construction of indicators, and graphical visualization of results in charts and maps.

- Add a web-based user interface to allow distributed use of model system, as shown in Figure 3.

- Develop institutional partnerships to fund the new regional model development, implementation, and maintenance.

\section{Long-term Implementation}

In the long-term (through 2007):

- Replace the traffic assignment component of the travel models with a dynamic microsimulation traffic assignment model using 5-10 minute time intervals. 
- Adapt the activity-based travel model to a continuous time (duration) approach to simulate travel demand using 5-10 minute time intervals, consistent with dynamic microsimulation traffic assignment.

- Expand the activity-based model to simulate travel demand for weekends. This would involve conducting an additional household travel survey on weekend days of 2-3,000 households.

- Adapt the regional economic model to a multi-region model structure to support commodity-freight transport and better reflect economic linkages to other urban areas within and near Washington.

- Expand and update the commodity-transport model component linked to the multi-region economic model.

- Develop an extended scenario evaluation component, incorporating least-cost planning, risk and uncertainty analysis, and valuation of social and environmental externalities.

\section{CONCLUSIONS}

The practice of land use and transportation planning is evolving rapidly, and analytical tools to support these evolving requirements are needed. Substantial progress in disaggregate land use modeling and in activitybased travel modeling provide a solid foundation to build on, but more work is needed to implement a behaviorally based and integrated modeling approach as outlined in these design recommendations.

The vast majority of the benefits to implementing the recommendations are those associated directly with addressing the design requirements, which are stated needs that the model users have identified. These benefits are not easily quantifiable, specifically because they reach much farther than the benefits to the Puget Sound Regional Council directly and will benefit all member agencies. The new models will allow the PSRC and its member agencies to address many more planning applications than they are able to do with the current models. These are summarized below:

- Evaluate freight mobility projects and their impacts on passenger mobility

- Evaluate transportation pricing policies and their impacts on travel and land use choices

- Evaluate Transit Oriented Design (TOD) projects and their impacts on local areas

- Evaluate congestion management system (CMS) and transportation system management (TSM) policies

- Evaluate Intelligent Transportation Systems (ITS) projects

- Evaluate traffic operations and localized impacts

- Evaluate impacts of visitor travel

- Evaluate impacts of weekend travel on the environment and provides better information on weekly, monthly or annual impacts

- Evaluate the impacts of the full range of transportation projects on land use

- Provide for least-cost planning, risk and uncertainty analysis and valuation of social and environmental externalities

The new models are also designed to be more useful and user-friendly to PSRC and its member agencies, as well as to other model users. Highlights of these proposed user interface features are summarized below:

- Integrates land use and activity-based travel models in a single software package

- Allows for diagnosing data quality and consistency and provides integration of data inputs for modeling with a new data integration component

- Adds graphic visualization of results and flexible construction of performance indicators

- Allows distributed use of models and model results through a web-based user interface

It may be important to note that there are additional benefits to member agencies than those directly addressing the stated model requirements. These benefits are derived primarily from the recommendations to use disaggregate data throughout the process. These disaggregate data would allow member agencies to use the new PSRC models directly for local and subarea studies within their jurisdictions, thus saving time and effort spent in disaggregating the regional models for these purposes. The resources currently spent by the member agencies to disaggregate regional data for local use could then be spent in maintaining and updating the disaggregate data used in the new PSRC models. Consistency of data and models used by the PSRC and its members is a significant potential benefit from implementation of these recommendations. 
The advantages of developing new integrated land use and activity-based models using disaggregate data and a behavioral basis throughout cannot be over-stated. These models are inherently more logical and are more accurate in aggregate form than their aggregate, 4-step planning model counterparts because they are based on the same decision-making choices that are present in the real world for both land use and travel decisions.

Unfortunately, the benefits of improved accuracy and reliability at this point are largely anecdotal or qualitative, since there are not direct comparisons between the proposed modeling techniques and current state of the practice. It may be important to note that they are not necessarily more accurate in the base year validation statistics, since models can be "tweaked" to match observed values, but would be more accurate in the forecast years. Comparisons of improved land use and activity-based models that are compared to existing techniques completed in other metropolitan areas should be reviewed when they become available to better understand these impacts. 


\section{REFERENCES}

Bakkenta, Ben. Associate Planner, PSRC. Phone interview. November 27, 2000.

Blue Ribbon Commission on Transportation (2000). Final Recommendations to the Governor and Legislature. http://www.brct.wa.gov/ Accessed December 18, 2000.

Kitchen, Matthew. Senior Planner, PSRC. Phone interview. November 20, 2000.

Pfundt, Joel. Senior Planner. PSRC. Phone interview. January 2, 2001.

Puget Sound Regional Council (1991). Framework Plan, Interlocal Agreement, Bylaws, Policy Board Appointment Policy. Puget Sound Regional Council.

Puget Sound Regional Council (1998). Interlocal Agreement for Regional Planning in the Central Puget Sound Area. Puget Sound Regional Council.

Puget Sound Regional Council (1999). Population and Housing Estimates: 1999. http://www.psrc.org/datapubs/pubs/pophsg99-pop.htm. Accessed November 21, 2000.

Puget Sound Regional Council (July 1999) 1999 Population and Employment Working Forecasts. http://www.psrc.org/datapubs/pubs/forecasts_1999.pdf. Accessed December 18, 2000.

United States Census (February 2001). Components of Population Change: 1990-2000. Available on the State of Washington Office of Financial Management web site at http://www.ofm.wa.gov/census2000/index.htm. Accessed April 10, 2001. 
Table 1.Land Use Models Concerns Identified by Professional Users

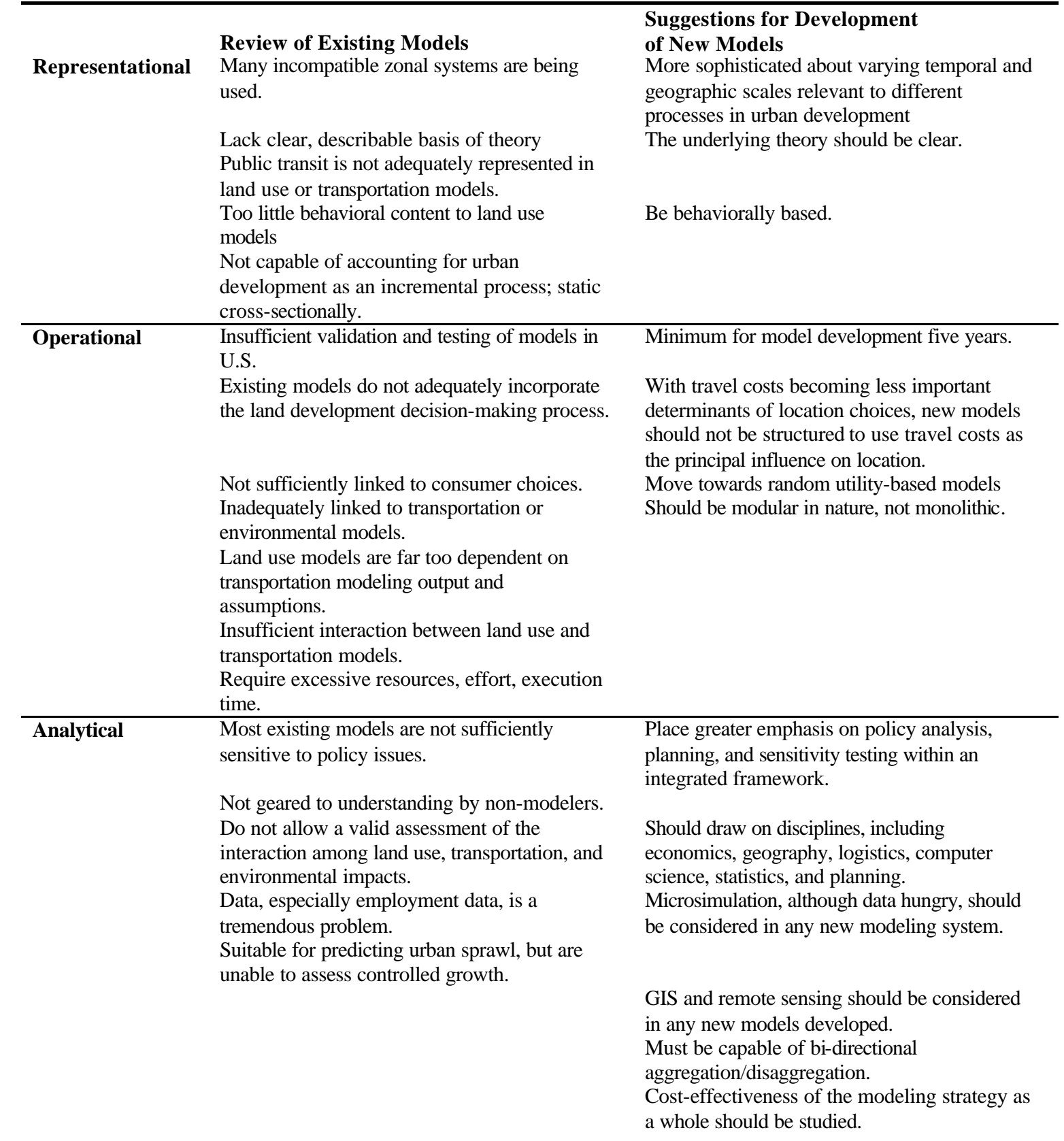


TABLE 2 Survey Respondents by Job Focus and Jurisdictional Level

\begin{tabular}{|l|l|l|l|l|l|l|}
\hline & City & County & Region & State & $\begin{array}{l}\text { Non- } \\
\text { governmental }\end{array}$ & Total \\
\hline Environment & & 1 & 1 & & 2 & 4 \\
\hline Land use & 5 & & 7 & & & 12 \\
\hline Transportation & 8 & 11 & 17 & 8 & 1 & 45 \\
\hline
\end{tabular}

The row headings indicate the focus of the organization where respondents work; the column headings show the scale of the jurisdictions. 
TABLE 3 Summary of User Needs Survey Results

\begin{tabular}{|c|c|c|c|c|c|c|}
\hline Category & Description & $\begin{array}{l}\text { Very } \\
\text { Imp. }\end{array}$ & Imp. & $\begin{array}{l}\text { Not } \\
\text { Imp. }\end{array}$ & $\begin{array}{c}\text { Avg. } \\
\text { Rating }\end{array}$ & $\begin{array}{c}\text { Oppos } \\
\text { ed }\end{array}$ \\
\hline & & $(2)$ & (1) & $(0)$ & & (omit) \\
\hline \multirow[t]{6}{*}{ Policy } & $\begin{array}{l}\text { Analyze Effects of Transportation } \\
\text { Pricing Policies }\end{array}$ & 30 & 26 & 1 & 1.51 & 1 \\
\hline & $\begin{array}{l}\text { Analyze Effects of Growth } \\
\text { Management Policies }\end{array}$ & 32 & 24 & 3 & 1.49 & 0 \\
\hline & Analyze Effects of Land Use Policies & 38 & 19 & 2 & 1.61 & 0 \\
\hline & $\begin{array}{l}\text { Analyze Short and Long Term Policy } \\
\text { Effects }\end{array}$ & 20 & 33 & 5 & 1.26 & 1 \\
\hline & Support Participatory Policy Process & 23 & 22 & 12 & 1.19 & 0 \\
\hline & Support Scenario Assessment & 25 & 26 & 5 & 1.36 & 1 \\
\hline \multirow[t]{6}{*}{ Travel demand } & $\begin{array}{l}\text { Analyze Travel Using Activity-Based } \\
\text { Framework }\end{array}$ & 22 & 30 & 4 & 1.32 & 0 \\
\hline & Analyze All Modes of Travel & 37 & 20 & 1 & 1.62 & 0 \\
\hline & $\begin{array}{l}\text { Analyze Effects of Land Use on } \\
\text { Transportation }\end{array}$ & 45 & 14 & 0 & 1.76 & 0 \\
\hline & Analyze Induced Demand & 26 & 28 & 2 & 1.43 & 1 \\
\hline & $\begin{array}{l}\text { Analyze Effects of Environmental } \\
\text { Factors }\end{array}$ & 12 & 26 & 17 & 0.91 & 4 \\
\hline & $\begin{array}{l}\text { Analyze Effects of Travel Demand } \\
\text { Management }\end{array}$ & 22 & 29 & 6 & 1.28 & 0 \\
\hline \multirow[t]{8}{*}{ Land use/demographics } & $\begin{array}{l}\text { Analyze Effects of Transportation on } \\
\text { Land Use }\end{array}$ & 29 & 28 & 1 & 1.48 & 1 \\
\hline & Analyze Effects of Urban Design & 23 & 27 & 9 & 1.24 & 0 \\
\hline & Analyze Household Choices & 11 & 39 & 8 & 1.07 & 0 \\
\hline & Analyze Household Choice Interaction & 14 & 33 & 11 & 1.05 & 0 \\
\hline & Analyze Demographic Processes & 20 & 31 & 8 & 1.20 & 0 \\
\hline & Analyze Real Estate Development & 14 & 35 & 9 & 1.09 & 1 \\
\hline & Support Analysis of TOD & 21 & 28 & 8 & 1.23 & 1 \\
\hline & Analyze Economic Activity & 14 & 27 & 15 & 0.98 & 2 \\
\hline \multirow[t]{2}{*}{ Freight } & $\begin{array}{l}\text { Analyze Commodity and Freight } \\
\text { Transport }\end{array}$ & 24 & 26 & 7 & 1.30 & 0 \\
\hline & $\begin{array}{l}\text { Analyze Modal Diversion of Goods } \\
\text { Movement }\end{array}$ & 14 & 28 & 14 & 1.00 & 1 \\
\hline \multirow{3}{*}{$\begin{array}{l}\text { Traffic assignment and } \\
\text { operation }\end{array}$} & Analyze Multimodal Assignments & 45 & 11 & 2 & 1.74 & 0 \\
\hline & Analyze Traffic Operations & 16 & 30 & 11 & 1.09 & 1 \\
\hline & $\begin{array}{l}\text { Analyze Intelligent Traffic Systems } \\
\text { (ITS) }\end{array}$ & 7 & 31 & 18 & 0.80 & 2 \\
\hline \multirow{6}{*}{$\begin{array}{l}\text { Data/visualization and } \\
\text { evaluation }\end{array}$} & Promote Common Use of Data & 38 & 16 & 2 & 1.64 & 0 \\
\hline & Manage Data Needs & 37 & 17 & 2 & 1.63 & 0 \\
\hline & Achieve Reasonable Performance & 16 & 24 & 13 & 1.06 & 1 \\
\hline & Support Visualization Techniques & 34 & 21 & 2 & 1.56 & 1 \\
\hline & $\begin{array}{l}\text { Allow Multimodal Cost-Benefit } \\
\text { Analysis }\end{array}$ & 20 & 30 & 6 & 1.25 & 1 \\
\hline & Perform Uncertainty Analysis & 16 & 21 & 17 & 0.98 & 2 \\
\hline
\end{tabular}


TABLE 4 Land Use Model Recommendations

\begin{tabular}{|c|c|c|}
\hline Element & $\begin{array}{l}\text { Options and Recommendations } \\
\text { (in bold) }\end{array}$ & Reasons for Recommendation \\
\hline Temporal Framework & $\begin{array}{l}\text { Cross-Sectional * } \\
\text { Dynamic }\end{array}$ & $\begin{array}{l}\text { Accommodates many different timescales } \\
\text { relevant to land use; } \\
\text { More useful for policy analysis; } \\
\text { Consistent with behavioral approach; } \\
\text { Can take advantage of panel survey data }\end{array}$ \\
\hline Temporal Detail & $\begin{array}{l}\text { End-point forecast } \\
\text { 5-10 year steps * } \\
\text { Annual }\end{array}$ & Best practice in the U.S. \\
\hline Spatial Detail & $\begin{array}{l}\text { Forecast Analysis Zones (50-200) * } \\
\text { Traffic Analysis Zones } \\
\text { Grid Cells ( } 30-150 \text { meters) } \\
\text { Parcels }\end{array}$ & $\begin{array}{l}\text { Easy to check for data errors; } \\
\text { Good for policy analysis; } \\
\text { Partial Data is available for PSRC region }\end{array}$ \\
\hline Theoretical Frameworks & $\begin{array}{l}\text { Spatial Interaction* } \\
\text { Spatial Input Output } \\
\text { Behavioral/Decision-Theoretic }\end{array}$ & $\begin{array}{l}\text { Behavioral realism; } \\
\text { Transparency needed for credibility; } \\
\text { Good for policy analysis; } \\
\text { Unifying approach for model }\end{array}$ \\
\hline Analytical Methods & $\begin{array}{l}\text { Optimization * } \\
\text { Discrete Choice } \\
\text { Bayesian }\end{array}$ & Allows modeling of choices \\
\hline Agent Detail & $\begin{array}{l}\text { Aggregate cross-classification into } \\
\text { types* } \\
\text { Microsimulation list with attributes }\end{array}$ & $\begin{array}{l}\text { More efficient to maintain list of attributes than } \\
\text { many cross-classifications; } \\
\text { Ease of maintaining database; } \\
\text { Supports equity analysis; } \\
\text { Supportive of discrete choice framework } \\
\text { because uses disaggregate data; } \\
\text { With many cross-classifications, data unwieldy. }\end{array}$ \\
\hline $\begin{array}{l}\text { Land Use-Travel Model } \\
\text { Integration }\end{array}$ & $\begin{array}{l}\text { Loosely coupled * } \\
\text { Integrated }\end{array}$ & $\begin{array}{l}\text { Consistent approach;Reflect substitutions } \\
\text { across short and long-term choice behavior. }\end{array}$ \\
\hline $\begin{array}{l}\text { Macro-economic Model } \\
\text { Integration }\end{array}$ & $\begin{array}{l}\text { Link to STEP Model in mid-term * } \\
\text { Develop Multi-region Hybrid I/O- } \\
\text { Econometric Model in long-term }\end{array}$ & $\begin{array}{l}\text { Support freight modeling;Interact with } \\
\text { statewide scale models; } \\
\text { Incorporate bottom-up effects of policies. }\end{array}$ \\
\hline User-specified Events & $\begin{array}{l}\text { No direct representation * } \\
\text { Accommodate user-specified events: } \\
\text { major development, business, or } \\
\text { policy change }\end{array}$ & $\begin{array}{l}\text { Recognize limitations of models to predict } \\
\text { events such as a major corporate relocation; } \\
\text { Do sensitivity analysis on effects of an event; } \\
\text { Incorporate information available to planners. }\end{array}$ \\
\hline
\end{tabular}

* Denotes current practice at PSRC 
TABLE 5 Passenger Travel Model Recommendations

\begin{tabular}{|c|c|c|}
\hline Element & $\begin{array}{l}\text { Options and Recommendations } \\
\text { (in bold) }\end{array}$ & Reasons for Recommendation \\
\hline Time-Unit for Analysis & $\begin{array}{l}\text { Weekday } * \\
\text { Weekday and Weekend } \\
\text { Entire week }\end{array}$ & $\begin{array}{l}\text { Captures different characteristics of } \\
\text { weekend and weekdays (i.e., peaking } \\
\text { characteristics); } \\
\text { Supports air quality analysis. }\end{array}$ \\
\hline $\begin{array}{l}\text { Intra-individual variations } \\
\text { in activity-travel pattern }\end{array}$ & $\begin{array}{l}\text { Ignored (i.e., the activity-travel pattern is } \\
\text { modeled based on data from one weekday } \\
\text { or one weekend day or one week, } \\
\text { depending on the time unit used in the } \\
\text { analysis) }{ }^{*} \\
\text { Recognized (requires multiple time-unit } \\
\text { observations) }\end{array}$ & $\begin{array}{l}\text { Data limitations } \\
\text { No operational models that include } \\
\text { this. }\end{array}$ \\
\hline Temporal Representation & $\begin{array}{l}\text { Discrete with further consideration of } \\
\text { continuous } \\
\text { Peak versus off-peak } * \\
\text { More disaggregate time periods (for } \\
\text { example, } 4-6 \text { time periods in the day) } \\
\text { Continuous-time }\end{array}$ & $\begin{array}{l}\text { Use five or six time periods for better } \\
\text { temporal resolution; } \\
\text { Supports policy analysis (i.e., } \\
\text { congestion pricing); } \\
\text { Practical implementation issues to } \\
\text { move towards continuous }\end{array}$ \\
\hline Spatial Detail & $\begin{array}{l}\text { Forecast Analysis Zones (50-200) } \\
\text { Traffic Analysis Zones * } \\
\text { Grid Cells ( } 30-150 \text { meters) } \\
\text { Parcels }\end{array}$ & Same as land use model reasons \\
\hline Behavioral Analysis & $\begin{array}{l}\text { Aggregate trip-based approach } * \\
\text { Disaggregate trip-based approach with no } \\
\text { interactions among trips } \\
\text { Disaggregate trip-based approach with } \\
\text { indirect recognition of interactions among } \\
\text { trips } \\
\text { Disaggregate tour-based approach with } \\
\text { interactions among stops in a tour, but no } \\
\text { interactions among tours Disaggregate tour- } \\
\text { based approach with indirect recognition of } \\
\text { interactions among tours } \\
\text { Activity-based approach with explicit } \\
\text { interactions among tours and stops }\end{array}$ & $\begin{array}{l}\text { Supports policy analysis (i.e., } \\
\text { congestion pricing); } \\
\text { Recognizes choices of household } \\
\text { members }\end{array}$ \\
\hline Modeling Focus & $\begin{array}{l}\text { Trip generation* } \\
\text { Activity scheduling only; considers activity } \\
\text { generation as pre-determined; i.e., assumes } \\
\text { that number of stops of each activity type, } \\
\text { and one or more attributes of the stops as } \\
\text { given and models sequencing and time- } \\
\text { scheduling of entire activity-travel pattern } \\
\text { Activity generation and scheduling, but no } \\
\text { explicit integration with traffic assignment } \\
\text { Activity generation and scheduling, with } \\
\text { no explicit integration with traffic }\end{array}$ & $\begin{array}{l}\text { The current activity-based models are } \\
\text { implemented this way so this is a } \\
\text { practical limitation }\end{array}$ \\
\hline
\end{tabular}

\footnotetext{
* Denotes current practice at PSRC
} 
TABLE 5 Passenger Travel Model Recommendations (Continued)

\begin{tabular}{|l|l|l|}
\hline Element & $\begin{array}{l}\text { Options and Recommendations } \\
\text { (in bold) }\end{array}$ & Reasons for Recommendation \\
\hline Interaction Considerations & $\begin{array}{l}\text { Interaction in activity-travel and car } \\
\text { allocation decisions among individuals in a } \\
\text { household } \\
\text { Interaction in space and time Interaction } \\
\text { between in-home and out-of-home activities }\end{array}$ & $\begin{array}{l}\text { Shows tradeoffs in choices } \\
\text { (In all these cases, the interactions } \\
\text { may be ignored or may be considered } \\
\text { at one of several different levels of } \\
\text { comprehensiveness) }\end{array}$ \\
\hline Analytical Methods & $\begin{array}{l}\text { Cross-classification } * \\
\text { Gravity methods } * \\
\text { Statistical (based on pattern-recognition or a } \\
\text { variant of this technique) } \\
\text { EconometricDiscrete choice } *\end{array}$ & \\
& $\begin{array}{l}\text { Allows for validation of model } \\
\text { Hazard duration systems } \\
\text { Structural equation systems } \\
\text { Rule-based computational-process systems } \\
\text { Linear and/or Non-linear optimization } \\
\text { formulations } \\
\text { Combinations of the above }\end{array}$ & \\
\hline Agent Detail & $\begin{array}{l}\text { Microsimulation list with attributes } \\
\text { Aggregate cross-classification into types } *\end{array}$ & Same as land use model reasons \\
\hline
\end{tabular}

* Denotes current practice at PSRC 
TABLE 6 Freight Forecasting Model Recommendations

\begin{tabular}{|c|c|c|}
\hline Element & $\begin{array}{l}\text { Options and Recommendations } \\
\text { (in bold) }\end{array}$ & Reasons for Recommendation \\
\hline Time Unit for Analysis & $\begin{array}{l}\text { Weekday } \\
\text { Weekday and Weekend } \\
\text { Entire week }\end{array}$ & Data currently available \\
\hline Temporal Representation & $\begin{array}{l}\text { Discrete-time } \\
\text { Peak versus off-peak } \\
\text { More disaggregate time periods (for example, } \\
\text { 4-6 time periods in the day) } \\
\text { Continuous-time }\end{array}$ & $\begin{array}{l}\text { Shows trucker response to congestion } \\
\text { Recognizes different temporal } \\
\text { patterns of trucks and autos }\end{array}$ \\
\hline Spatial Detail & $\begin{array}{l}\text { Forecast Analysis Zones (50-200) } \\
\text { Traffic Analysis Zones } \\
\text { Grid Cells (30 - } 150 \text { meters) } \\
\text { Parcels }\end{array}$ & Same as land use models \\
\hline Representation of Objects & $\begin{array}{l}\text { Trucks } \\
\text { Commodities by Weight and Value } \\
\text { Parcels/Boxes/Shipments }\end{array}$ & $\begin{array}{l}\text { Standard practice } \\
\text { Allows for translation to mode and } \\
\text { time }\end{array}$ \\
\hline Agent Detail & $\begin{array}{l}\text { Aggregate cross-classification into types } \\
\text { Microsimulation list with attributes }\end{array}$ & Data available \\
\hline Model Approach & $\begin{array}{l}\text { Commodity Flow } \\
\text { Vehicle Models } \\
\text { Hybrid Approach }\end{array}$ & $\begin{array}{l}\text { Use Commodity } \\
\text { Flow approach for regional/national } \\
\text { and international movements } \\
\text { Use Vehicle Model approach for } \\
\text { local or internal truck trips }\end{array}$ \\
\hline $\begin{array}{l}\text { Commodity Flow Model } \\
\text { Elements }\end{array}$ & $\begin{array}{l}\text { Small-area projections of employment and/or } \\
\text { commodity 'flow ends' } \\
\text { Mode choice models reflecting shippers' and } \\
\text { carriers' decisions } \\
\text { Flow models for various types of pickup and } \\
\text { delivery, collection and distribution operations }\end{array}$ & \\
\hline Vehicle Model Elements & $\begin{array}{l}\text { Trip generation relationships based on other } \\
\text { variables besides employment: locational } \\
\text { variables such as prevailing land use and } \\
\text { employment density } \\
\text { Additional trip distribution and traffic } \\
\text { assignment variables besides travel time: } \\
\text { times weighted lower on truck routes and } \\
\text { numbered highways, distance, grades, land } \\
\text { use matches at origin and destination. }\end{array}$ & \\
\hline
\end{tabular}

There are currently no freight forecasting models at PSRC, so current practice is not noted on this table. 
TABLE 7 Assignment and Traffic Operations Models

\begin{tabular}{|c|c|c|}
\hline Element & $\begin{array}{l}\text { Options and Recommendations } \\
\text { (in bold) }\end{array}$ & Reasons for Recommendation \\
\hline Temporal Representation & $\begin{array}{l}\text { Discrete-time for regional analysis } \\
\text { More disaggregate time periods (for } \\
\text { example, } 4-6 \text { time periods in the day) } \\
\text { Continuous-time or } \mathbf{5 / 1 5} \text { minute time } \\
\text { slices for subareas } \\
\text { Peak versus off-peak } *\end{array}$ & $\begin{array}{l}\text { Consistent with other model } \\
\text { elements }\end{array}$ \\
\hline Spatial Detail & $\begin{array}{l}\text { Traffic Analysis Zones with centroid } \\
\text { connector strategies and/or Multi-node } \\
\text { loading * } \\
\text { Point- or Link-based }\end{array}$ & $\begin{array}{l}\text { Supports micro-simulation for } \\
\text { subareas }\end{array}$ \\
\hline $\begin{array}{l}\text { Pedestrian and Bicycle } \\
\text { Networks }\end{array}$ & $\begin{array}{l}\text { None * } \\
\text { Separate networks } \\
\text { Representation of delay }\end{array}$ & Supports policy analysis \\
\hline \multicolumn{3}{|c|}{ Remaining Elements are provided with multiple options that are all recommendations } \\
\hline $\begin{array}{l}\text { Estimation of Speed and Travel } \\
\text { Time }\end{array}$ & $\begin{array}{l}\text { Functional forms to match HCM } \\
\text { relationships } \\
\text { Additional link variables - parking, } \\
\text { intersection spacing, lane widths, grades, } \\
\text { railroad crossings, etc. } \\
\text { Separate intersection and link delay } \\
\text { functionsWeaving sections } \\
\text { Measure variability to represent } \\
\text { reliability }\end{array}$ & $\begin{array}{l}\text { Estimation of Speed and Travel } \\
\text { Time }\end{array}$ \\
\hline Auto Passenger Assignments & $\begin{array}{l}\text { Multi-class assignments (SOV and HOV } \\
2, \mathrm{HOV} 3+\text { ) } \\
\text { Dynamic assignment/queuing: } \\
\text { Simplified strategies to model multi-link } \\
\text { back-ups due to bottlenecks, Time-slice } \\
\text { trip tables }\end{array}$ & Auto Passenger Assignments \\
\hline Transit Assignments & $\begin{array}{l}\text { Multi-path } * \\
\text { Capacity restrained (in vehicle or at Park } \\
\text { and Ride Lots) }\end{array}$ & Transit Assignments \\
\hline Truck Assignments & $\begin{array}{l}\text { Use of Passenger Car Equivalents } \\
\text { Multi-class Assignments by Truck Type } \\
\text { Use of Truck Networks, Prohibitions, and } \\
\text { Preferred Routes }\end{array}$ & Truck Assignments \\
\hline $\begin{array}{l}\text { Microsimulation Model } \\
\text { Elements }\end{array}$ & $\begin{array}{l}\text { The simulation unit: individual drivers } \\
\text { vs. 'packets' vs. flow rates } \\
\text { Transfer of O/D and network information } \\
\text { from assignment models } \\
\text { Driver behavior: gap acceptance, } \\
\text { acceleration, deceleration; individual vs. } \\
\text { typical } \\
\text { Random (stochastic) vs. average } \\
\text { characteristics }\end{array}$ & Microsimulation Model Elements \\
\hline
\end{tabular}

\footnotetext{
* Denotes current practice at PSRC
} 
TABLE 8 Recommendations for Representation

\begin{tabular}{|c|c|}
\hline Representation & Recommendations \\
\hline Agents & $\begin{array}{l}\text { Households */Persons } \\
\text { Businesses/Jobs * } \\
\text { Developers }\end{array}$ \\
\hline Objects & $\begin{array}{l}\text { Land* } \\
\text { Housing } \\
\text { Nonresidential Buildings } \\
\text { Households*/Persons* } \\
\text { Businesses/Jobs* } \\
\text { Political institutions/Boundaries } \\
\text { Environmental Features } \\
\text { Infrastructure (roads*, water, sewer, transit service*) } \\
\text { Policies }\end{array}$ \\
\hline $\begin{array}{l}\text { Land Use and } \\
\text { Demographic } \\
\text { Behavior }\end{array}$ & $\begin{array}{l}\text { Household Choices } \\
-\quad \text { Formation/dissolution/evolution, } \\
-\quad \text { Residential move } \\
\text { - } \quad \text { Location choice * } \\
\text { Business Choices } \\
\text { - } \quad \text { Creation/dissolution/expansion/ contraction, } \\
\text { - } \quad \text { Business move } \\
\text { - } \quad \text { Location choice (of jobs) } * \\
\text { Real Estate Development Choices } \\
\text { - Developer land development, } \\
\text { - } \quad \text { Developer property development and Developer redevelopment } \\
\text { Person Labor Market Choices } \\
\text { - } \quad \text { Labor market (active, inactive) } \\
\text { - } \quad \text { If employed, job change, place of work, hours of work/week, work arrangement } \\
\quad \text { (flexible versus fixed work schedule, telecommuting or not, compressed work week or } \\
\quad \text { regular work week.) } \\
\text { Household vehicle ownership * } \\
\text { Real estate prices (prices and rents) and vacancies } \\
\text { Labor market prices (wages) and vacancies }\end{array}$ \\
\hline Travel Behavior & $\begin{array}{l}\text { Allocation of activities and care among individuals in a household } \\
\text { Generation and scheduling of activities } \\
\text { - } \quad \text { Number of stops of each type, number of tours, } \\
\text { - } \quad \text { Number of stops during work commute, } \\
\text { - } \quad \text { Number of stops by type and sequence in each tour, } \\
\text { - } \quad \text { Mode choice of each tour, } \\
\text { - } \quad \text { Stop attributes (time-of-day of participation, activity duration, and location), and mode. }\end{array}$ \\
\hline
\end{tabular}


Analyze Effects of Transportation Pricing Policies Analyze Effects of Growth Management Policies

Analyze Effects of Land Use Policies Analyze Short and Long Term Policy Effects

Support Participatory Policy Process

Support Scenario Assessment

Analyze Travel Using Activity-Based Framework

Analyze All Modes of Travel

Analyze Effects of Land Use on Transportation

Analyze Induced Demand

Analyze Effects of Environmental Factors

Analyze Effects of Travel Demand Management

Analyze Effects of Transportation on Land Use

Analyze Effects of Urban Design

Analyze Household Choices

Analyze Household Choice Interaction

Analyze Demographic Processes

Analyze Real Estate Development

Support Analysis of TOD

Analyze Economic Activity

Analyze Commodity and Freight Transport Analyze Modal Diversion of Goods Movement

Analyze Multimodal Assignments

Analyze Traffic Operations

Analyze Intelligent Traffic Systems (ITS)

Promote Common Use of Data Manage Data Needs

Achieve Reasonable Performance

Support Visualization Techniques Allow Multimodal Cost-Benefit Analysis

Perform Uncertainty Analysis

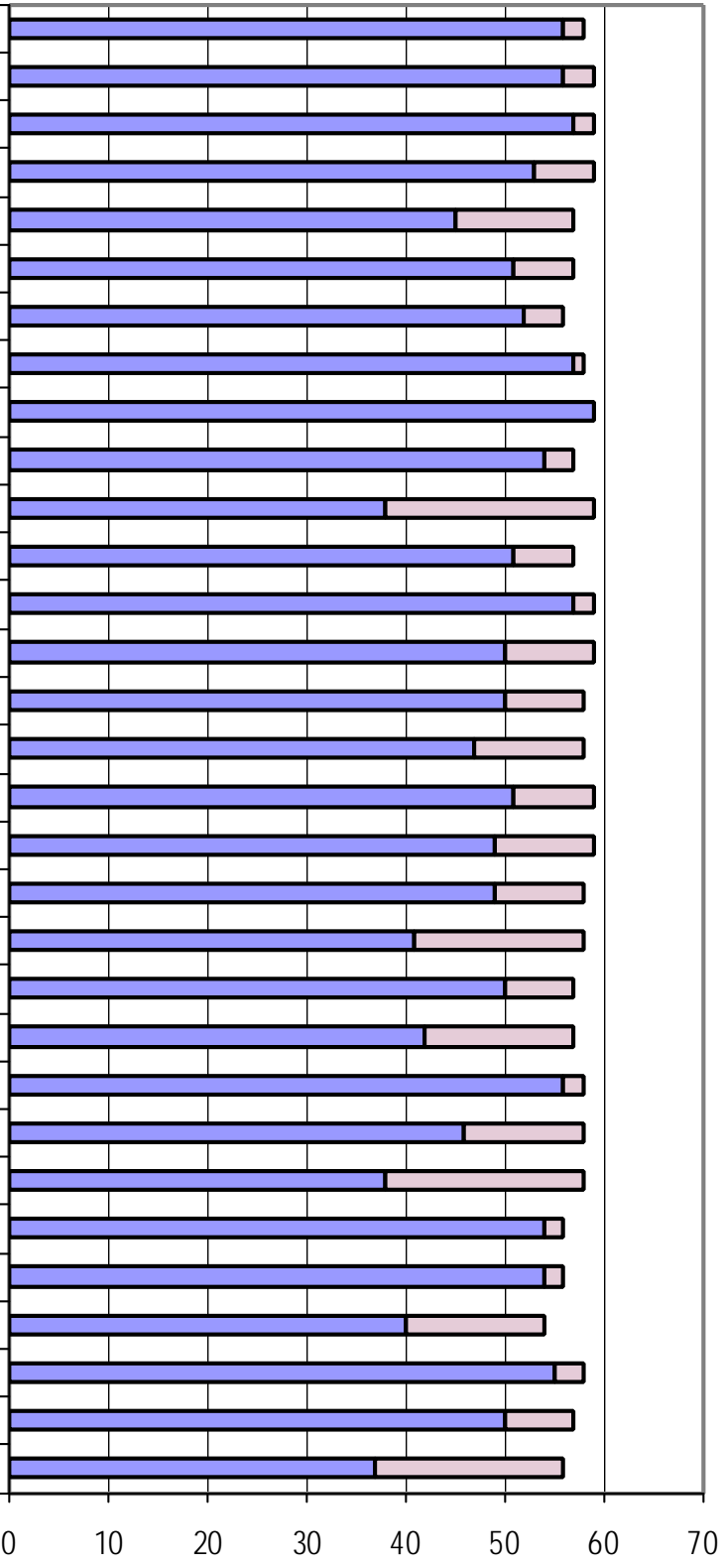

$\square$ Very Important/Important $\square$ Unimportant/Opposed

\section{FIGURE 1 Survey Ratings and Number of Responses}




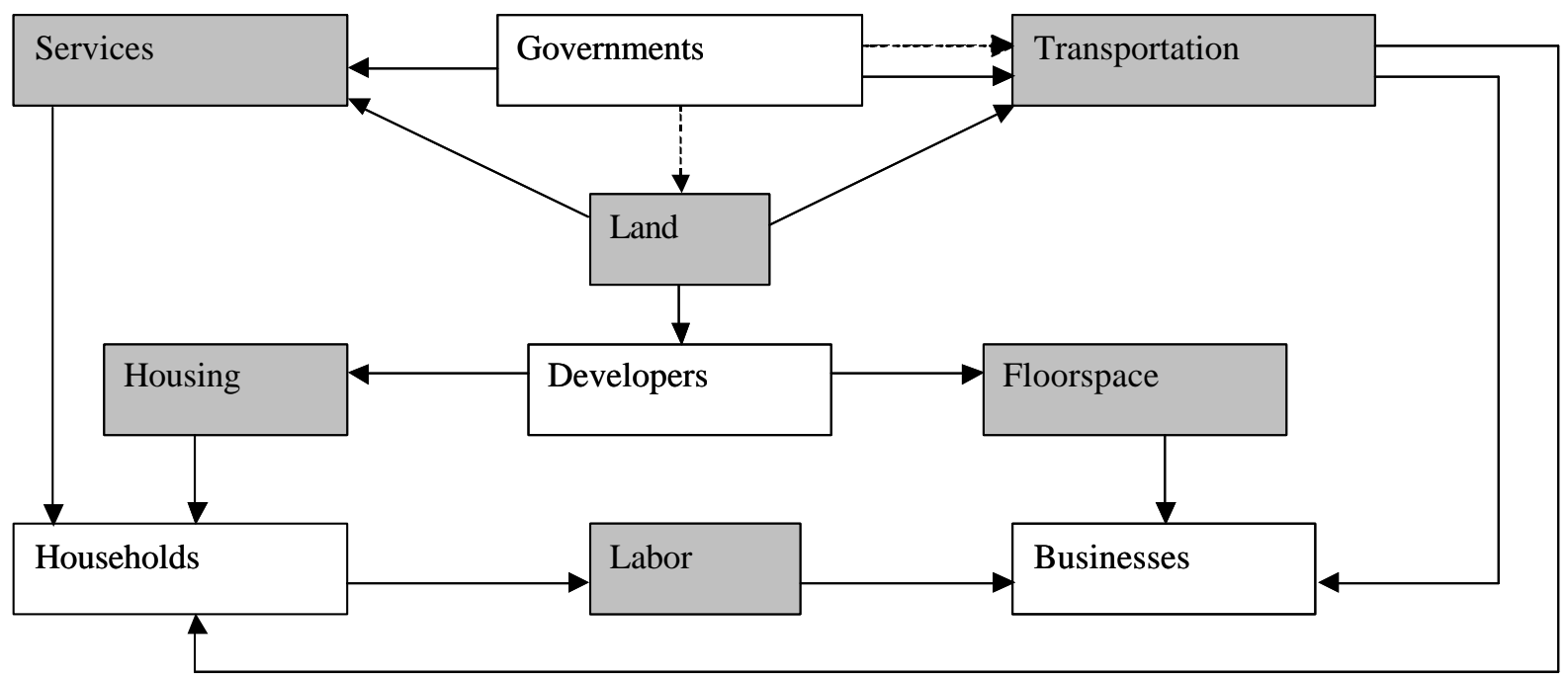

$\longrightarrow$ Flow of consumption from supplier to consumer

$\rightarrow$ Regulation or Pricing

FIGURE 2 Interacting Urban Markets 


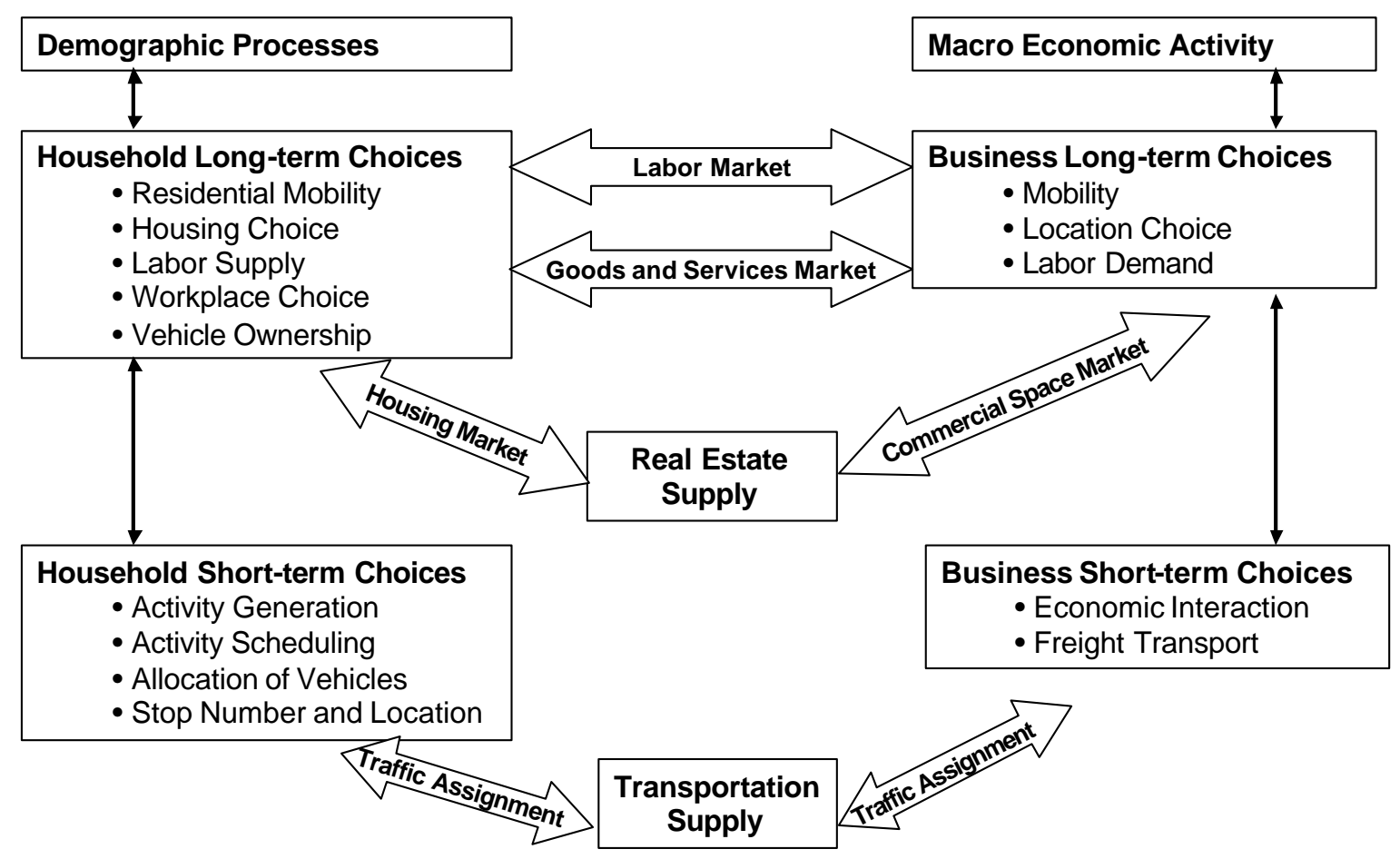

FIGURE 3 Model Design 


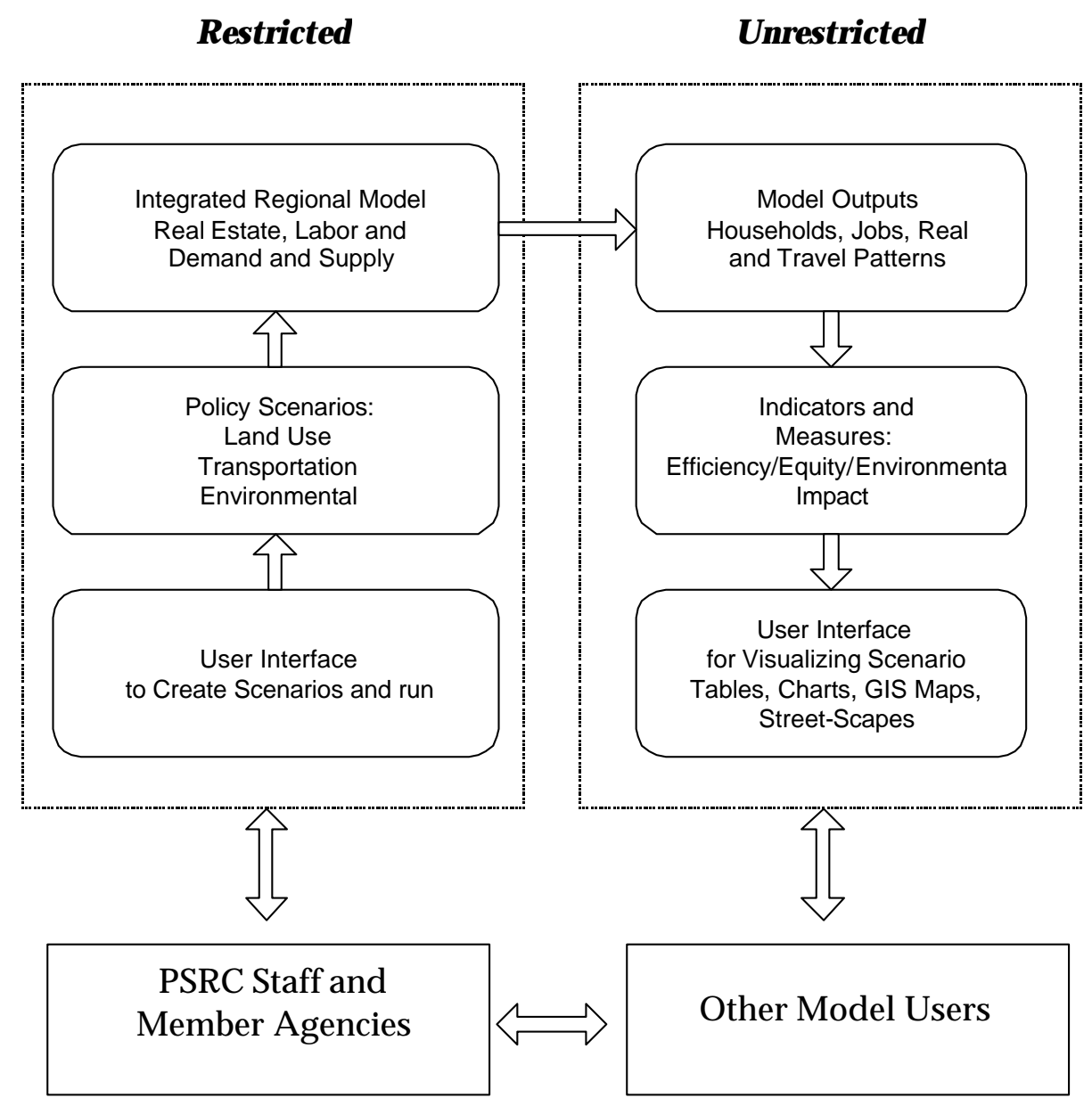

FIGURE 4 Web-based Model User Interface 